\title{
INTRASPECIFIC VARIATIONS IN FLOWERING PHENOLOGY OF AFRICAN PEAR (DACRYODES EDULIS (G. DON) H.J. LAM) FLOWERING IN SOUTH EAST NIGERIA
}

NJOKU, T.C*.

*Department of Crop Science \& Biotechnology, Imo State University, P. M. B 2000, Owerri, Imo

State, Nigeria.

E-mail: tcnjoku2011@yahoo.com

\begin{abstract}
A survey was carried out in two states, six locations of south east Nigeria during the normal flowering period for three (3) consecutive years to evaluate the intraspecific variations in flowering phenology of African pear flowering. The different types of the species growing in the forest, distant and nearby farms, including homesteads were used. 60 trees and 180 flowered branches were sampled for the survey. Parameters collected include time for flowering, number of flower per inflorescence, inflorescence length and number of inflorescence per panicle. Data collected were analysed using analysis of variance, regression and correlation. Standard errors and percentages were calculated where appropriate. Based on the observed floral nature, three distinct African pear tree species were identified - female, male and hermaphrodite trees. The time of flowering varied within and between locations. This ranged from December to March 2013 to 2015 for the period of study. Strong positive relationship exist between inflorescence length and flower per inflorescence. Significant $(p<0.05)$ differences were observed in mean flower per inflorescence and mean inflorescence per panicle in 2015 in Abia state. The mean inflorescence length, inflorescence per panicle and flower per inflorescence were statistically $(p<0.05)$ the same for 2014 and 2015 in Imo State. These ranged from $14.79 \mathrm{~cm}$ to $18.74 \mathrm{~cm}$, $13.81 \mathrm{~cm}$ to $18.60 \mathrm{~cm} ; 4.16$ to $5.66 ; 5.75$ to $6.61,21.40$ to 92.71 and 45.66 to 110.18 respectively. Inflorescence length and inflorescence per panicle were significantly $(p<0.05)$ different in 2013 in Imo State. In terms of the trees flowering circle, African pear can be seen as an annual since $57 \%$ to $77 \%$ of the trees flower annually, while $23 \%$ to $43 \%$ flower biennially and triennially. Therefore the survey study discovered that there are variations in floral natures, inflorescence length, inflorescence per panicle, flowering circle, and time of flowering in African pear. This study will be useful for breeding purposes in African pear.
\end{abstract}

Key words: African pear, survey, Intraspecific, flowering, phenology, variation.

https://dx.doi.org/10.4314/jafs.v19i2.2

\section{INTRODUCTION}

African pear tree (D. edulis (G.Don) H.J.Lam)) is a tropical evergreen fruit tree species (TFTS). The fruit is mainly available between the months of April to September when local farmers have planted their crops and there is food scarcity. It is normally eaten during this period with maize (Zea mays L.) to overcome hunger (Okorie, 2001). The flower is useful in apiculture while the fruit enhances nursing mothers' breast milk (Rocquelin et al., 1998). It is rich in high quality natural oil that can be used as a raw material for manufacturing soap, margarine, paints and candles. The leaf is medicinal. Its multi-purpose nature and socio- economic potentials has been discussed (Okorie et al., 2006; Opeke, 2012). African pear is a typical Journal of the Faculty of Agriculture and Veterinary Medicine, Imo State University Owerri website: www ajol.info 

home gardens (Leakey et al., 2008). African pear seed contains the following: lipid$12.45 \%$; protein- $1.24 \%$; sodium $0.87 \mathrm{mg} / 100 \mathrm{~g}$; iron $-0.80 \mathrm{mg} / 100 \mathrm{~g}$; calcium $0.13 \mathrm{mg} / 100 \mathrm{~g}$; potassium - $1.66 \mathrm{mg} / 100 \mathrm{~g}$; zinc $-0.31 \mathrm{mg} / 100 \mathrm{~g}$; phosphorus $-10.34 \mathrm{mg} / 100 \mathrm{~g}$; ash - 0.20\%; magnesium - 0.32mg/100g. (Ajayi and Adesonwe, 2009). African pear is rich in antioxidant, boost immune system, help in protein synthesis, promote skin health, reduces constipation, lowers high blood pressure, promote healthy bones and teeth, prevent cancer, they are allergy-free fruits, reduces the risk of diabetes, reduces agerelated diseases, good for pregnancy (Ajibesin, 2011). Despite all these benefits African pear has not been researched upon like other trees. The only horticultural fruit trees that have received research attention are the exotic fruit trees such as citrus (Citrus sinensis) and mango (Magnifera indica) (L). The few indigenous fruit trees that had been studied include oil palm (Elaeis guineensis jacq.) and the kola (Cola acuminate(P. Beauv.) Schott and Endl and Cola nitida (Vent) A.Chev) (Okorie et al.,2000).

Furthermore, African pear is little known outside its place of origin (Okorie, 2001). In addition, the industrial potentials, ecological and economic importance of this multipurpose tree species should not be neglected. Also, there is an increase steady decline in their numbers. All these are as a result of long term neglect of African pear in research which has given rise to a conspicuous lack of information in intraspecific variations in flowering phenology of the African pear flowering. This has greatly hampered efforts in the area of breeding and improvement of the species. If the environmental and humanitarian dimensions are to be important considerations in future agricultural development agenda, the bridging of the information gap is a necessity (Okorie et al.,2000).

There is a very great limited information on the species variability and commercial plantation requirements. This study therefore examined the intraspecific variations in flowering phenology of African pear (Dacryodes edulis (G. Don)H. J. lam) flowering.

\section{MATERIALS AND METHODS \\ 1. Experimental Location and Conditions}

The study was a survey work conducted for three years. Extensive field trips were made which covered both Imo and Abia States (South - East zone) of Nigeria where the species naturally occurs (Latitude $05^{0} 30^{1} \mathrm{~N}$; Longitude $07^{0} 24^{1}$ E Altitude $440 \mathrm{~m}$ ). This part of the humid tropics is characterized by a warm wet season (mid march to October) and a hot dry season (November to mid March). Most of the annual precipitation of 1,810 $2,260 \mathrm{~mm}$ falls during the wet season, which is broken by a short duration drought of $10-$ 14days in August. For much of the daytime during the wet season, the relative humidity is near saturation point and often with maximum and minimum temperature ranges from $30^{\circ} \mathrm{C}$ and $21^{\circ} \mathrm{C}$, respectively (NIMET, 2018).

African pear (Dacryodes edulis) trees growing in the forests distant and nearby farms, in addition to homesteads were used for the study. During the field survey study, photographs, line drawings, measurements and morphological observations were made on both the flowers, flower per inflorescence and inflorescence per panicle of the flowers. Measurements on floral characters were made at random from growing trees and replicated 10 times for each attribute in each tree sampled. Morphological observations were made on 180 different trees during the three consecutive flowering seasons.

The field survey were monitored morning and evening for floral character data collection for the period of the study. Floral characters studied are as follows: mean time of flower formation, number of flower per

Journal of the Faculty of Agriculture and Veterinary Medicine, Imo State University Owerri website: www ajol.info 
Volume 19, Number 2, October 2021, pp 13 - 22

inflorescence, number of inflorescence per panicle, and nature of inflorescence.

All linear measurements were taken with a measuring tape. Floral parts that were high on the tree top were observed and counted with the aid of a telescope. Microscope also were used to expose the different parts of the sampled flowers for observation and identification.

In addition to descriptive statistics and charts, the collected data were analyzed using randomized complete block design (RCBD) regression and correlation in statgraphics centurion XVI (16.0) software package. Significant means were separated using Duncan's new multiple range test (DNMRT). Correlation coefficients and coefficients of variation $(\mathrm{CV})$ were also used (GUPTA, 2011).

\section{RESULTS AND DISCUSSION}

Results of analysis of variance for intraspecific variations in flowering phenology of African pear are shown in Tables 1-6. A great deal of variations and similarities were observed in African pear inflorescence length, inflorescence per panicle and flower per inflorescence within and between the six locations covered in Imo and Abia states.

2013 showed significant $(p<0.05)$ difference in the mean values of inflorescence length obtained from IMSU and Umuduru locations. The mean values were $20.33 \mathrm{~cm}$ and $8.77 \mathrm{~cm}$ respectively (Table 1). Inflorescence length of African pear in Abia state were the same for the three years of study (Table 2). The highest mean inflorescence lengths were $19.07 \mathrm{~cm}$, $16.96 \mathrm{~cm}$ and $16.83 \mathrm{~cm}$ respectively. These showed that year of study and location had no significant $(p<0.05)$ effect on the inflorescence length. The mean number of inflorescence per panicle varied both between the locations and years in Imo state. Significant $(\mathrm{p}<0.05)$ difference were observed in 2013 with the following mean values: 5.18, Journal of the Faculty of Agriculture and Veterinary Medicine, Imo State University Owerri website: www ajol.info
3.46 and 1.57 respectively (Table 3 ). Significant $(\mathrm{p}<0.05)$ differences were also observed in the mean values of inflorescence per panicle at Abia State for 2013 and 2014. The highest mean values were 11.21 and 5.11, while the lowest means were 0.96 and 3.05 (Table 4). Number of flower per inflorescence in Imo state for 2013 to 2015 showed significant $(\mathrm{p}<0.05)$ differences in some location (Table 5). Also, with regard to flower per inflorescence at Abia State, the means were statistically $(\mathrm{p}<0.05)$ similar in 2013 and 2014 while in 2015 , they were significantly $(p<0.05)$ different (Table 6). This means that location and year had no effect on flower per inflorescence. Variations observed in flowering phenology of African pear may be more of genetic and less environmental hence these trees were found growing side by side in the same location under the same environmental condition. Variation exists in the nature of inflorescence and inflorescence length (Tables 1 and 2). Some inflorescence had only one finger, others had sub- finger and sub-sub fingers. These fingers bear the flowers. Some, one flower while others may carry up to three, five and seven flowers. The length of inflorescence varied greatly from $5.64 \mathrm{~cm}$ to $20.33 \mathrm{~cm}$. The shape and length of the inflorescence sometimes determine the sex of the tree (male, female or hermaphrodite flower). Inflorescence length was not affected by location and year. The numbers of flowers observed in an inflorescence were dependent on the length of the inflorescence (Table 5 and 6). The length of the inflorescence may be influenced by genetic. The number of panicle or inflorescence varied from year to year and between locations. The number of panicle per branch determine the intensity of flowering and it varied from year to year (Table 3 and 4). There were variations in the type of flowers. With the aid of the microscope, male, female and hermaphrodite flowers were identified (Plates 1-3). The number of flowers that form fruit is dependent 
on the ratio of male, female and hermaphrodite flowers which also was controlled genetically (Legave et al.,2008; Grab and Craparo, 2011).

At both locations flowering started from January till March. The peak of flowering at Imo State were during the month of January with the mean flowering value of 5.8, 7.0 and 5.4 for 2013 to 2015, (Fig.1) while February was the peak of flowering at Abia State with the mean flowering values of 2.7,3.6 and 2.7 for 2013 to 2015 respectively (Fig. 2). Differences in time of flowering within and between the various locations surveyed might be as a result of genetic and environmental factors prevalent at that point in time (Domingo et al.,2007). Therefore, observations made during the survey revealed some differences in the flowering phenology of African pear with regards to flowering habits (Fig.5and 6). At Imo State $74 \%$ were annual, $23 \%$ biennial and $3 \%$ triennial while Abia state had $57 \%, 33 \%$ and $10 \%$ for annual, biennial and triennial respectively.

\section{Conclusion}

African pear (Dacryodes edulis (G. Don) H. J. Lam) is a very important multipurpose tree used as food, medicine, livestock feed and ornamental purposes. A great deal of intraspecific variations of genetic interest exists in African pear (D. edulis) flower and flowering phenology to warrant the initiation of a planned phenological program for breeding, selection and improvement of African pear. Also, knowledge of phenology especially as it relates to flowering is particularly important for the breeding, development and improvement of the species. However, further studies should be required in the area of breeding for improvement of this indigenous and neglected tree species. 
Volume 19, Number 2, October 2021, pp 13 - 22.

\section{REFERENCES}

Ajayi and Adesonwe, O. (2009). Comparative study of the mineral element and fatty acid composition of Dacryodes edulis pulp and seed. World Journal. Agricultural Science, 5, 279 - 283.

Ajibesin, K.K. (2011). Dacryodes edulis Lam: A review of its medicinal photochemical and economic properties. Research Journal of Medicinal Plants, 51: 32 - 41. https://doi.org/10.3923/rjmp.2011.32.41

Gupta S.C. (2011) Fundamentals of statistics 6th edition

Leakey, R. R.B., Fuller, S., Treloar, T., Stevenson, L., Hunter, D., Nevenimo, T., Binifa, J. and Moxon, J. (2008). Characterization of tree-to-tree variation in morphological, nutritional and medicinal properties of Canarium indicum nuts. Agroforestry Systems 73, 77-87. https://doi.org/10.1007/s10457-007-9103-4

NIMET (2018) Nigerian Institute of Meterology.

Okorie, H. A., Janssens, M. J. J. and N dubuizu, T. O. C. (2000). Propagation and improvement of African pear (Dacryodes edulis (G. Don) HJ Lam): Problems and. improvement of African pear (Dacryodes edulis (G. Don) HJ Lam): Problems and prospects. Proceedings of the 2nd ISHS Conference on fruit production in the Tropics and Sub- tropics. Acta Hort. 531. doi.org/10.17660/ActaHortic.2000.531.34

Okorie, H. A. (2001). Furthering the domestication of African Pear (Dacryodes edulis (G.Don) H.J. Lam Shaker Verlag publishers. 91Pp.

Okorie, H. A., Ezeanyika, S. E. and Marx, F. (2006). Oil potentials of three African pear (Dacryodes edulis (G.Don) HJ Lam ) fruit types. Journal of Agricultural and Food Sciences, 4(1).

Opeke. L. K., (2012).Tropical Commodity Tree Crop. Spectrum Books Limited, Ibadan.

Rocquelin, G., Tapsoba, S., Dop, M. C., Mbembe, F., Traissa, P., Martin-Prevel, Y. (1998). Lipid content and essential acid (EFA) Composition of mature Congolese breast milk are influenced by mothers nutritional status: Impact on infants' EFA supply. European Journal of Clinical Nutrition. $\quad 52, \quad 164-171$. https://doi.org/10.1038/sj.ejcn.1600529 


\section{APPENDIX}

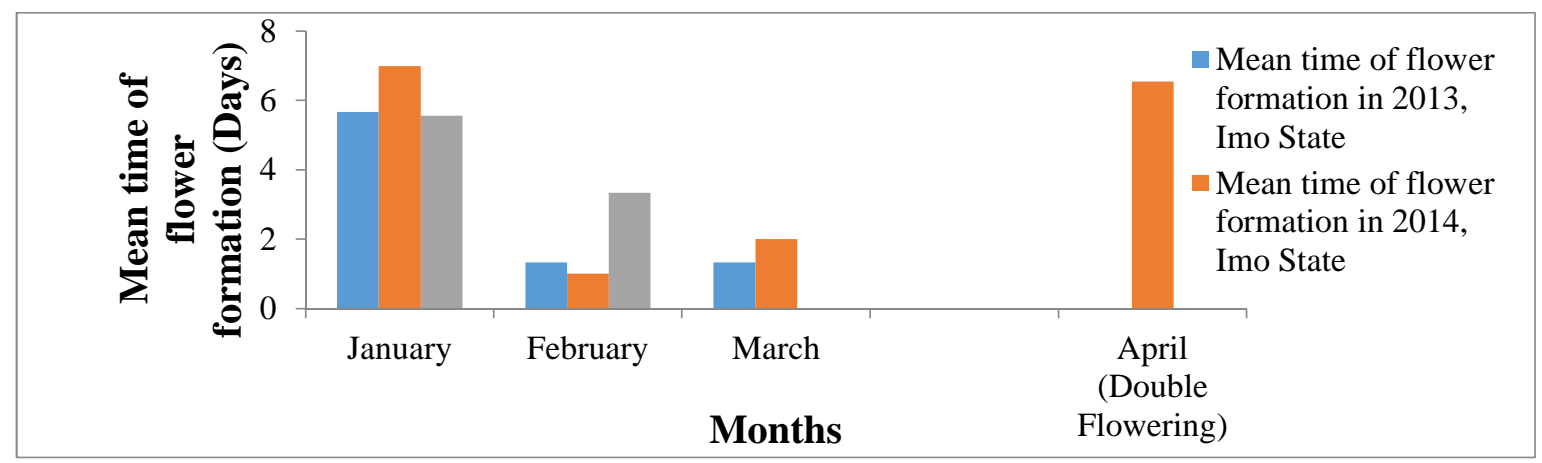

Figure 1: Mean time of flower formation in Imo State from 2013- 2015.

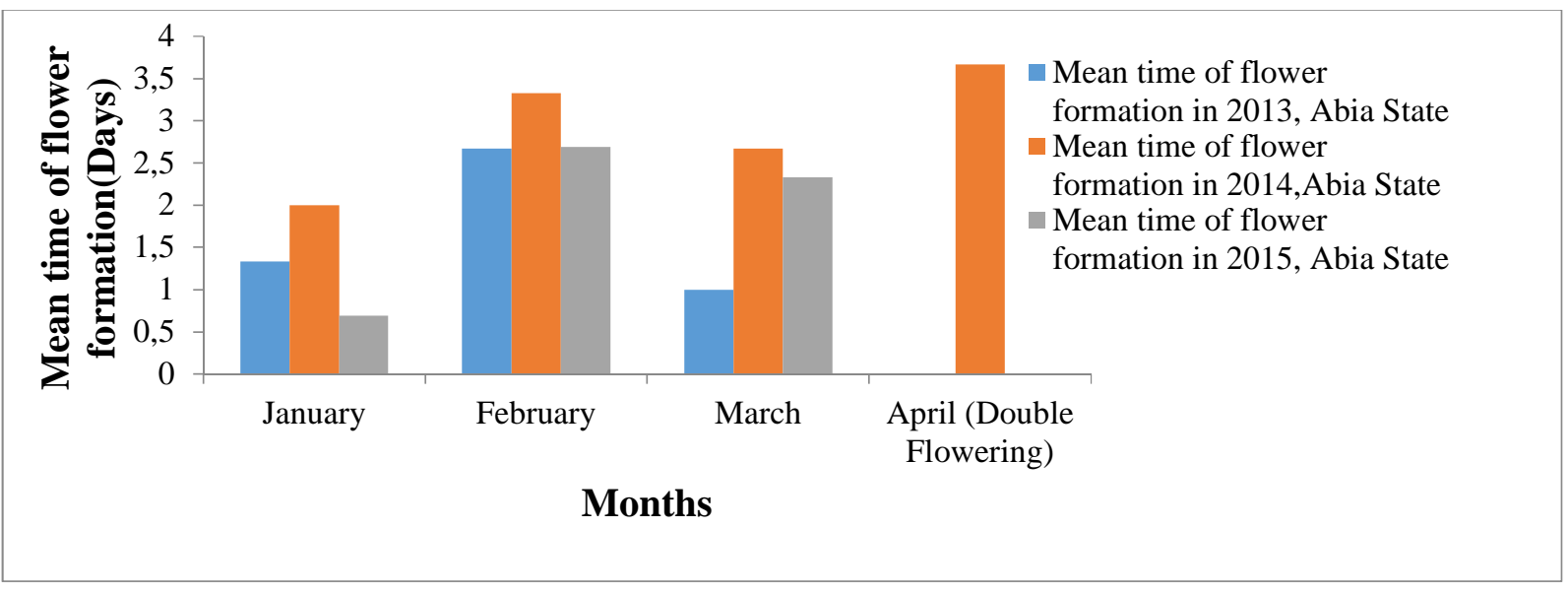

Figure 2: Mean time of flower formation in Abia State from 2013- 2015.

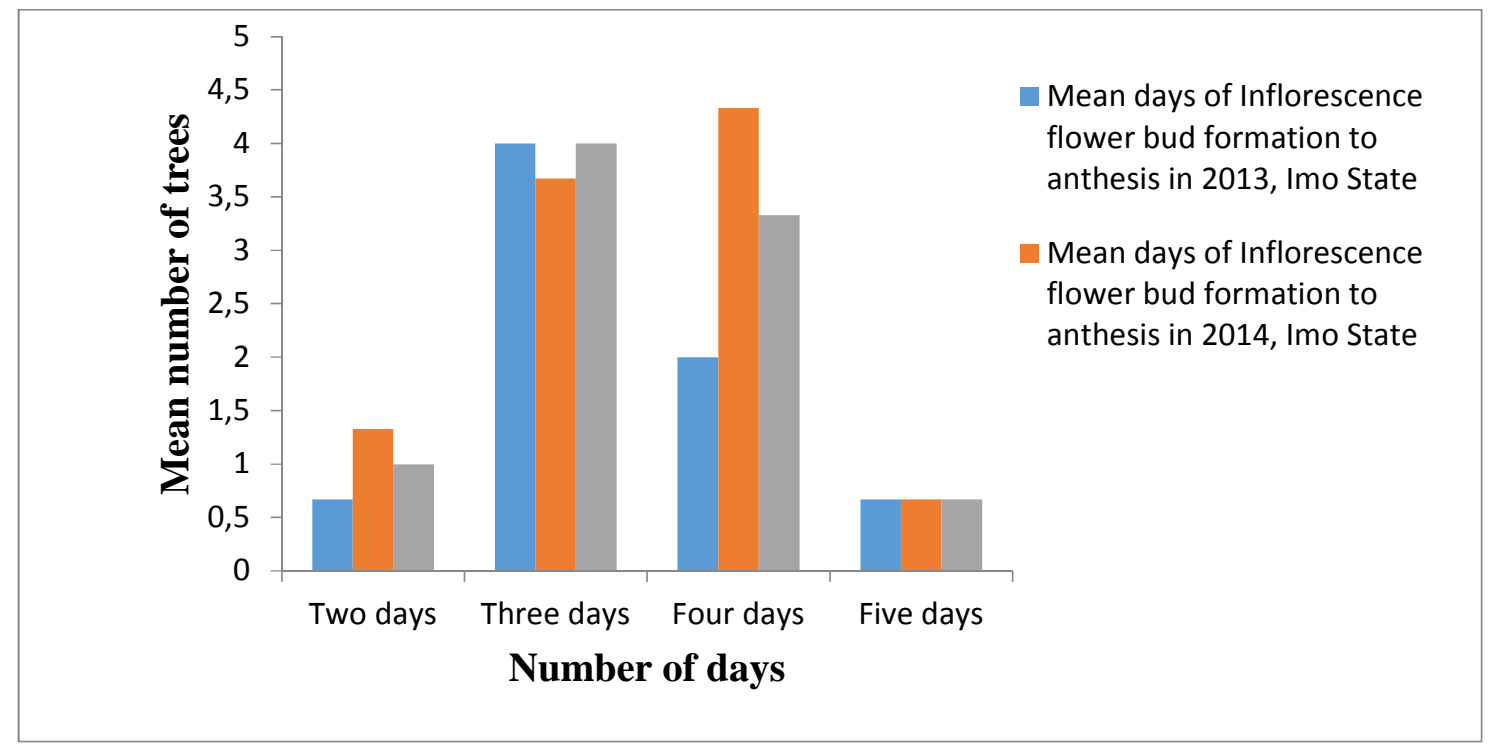

Figure 3: Mean days of inflorescence flower bud formation to anthesis from $2013-2015$ in Imo State

Journal of the Faculty of Agriculture and Veterinary Medicine, Imo State University Owerri website: www ajol.info 


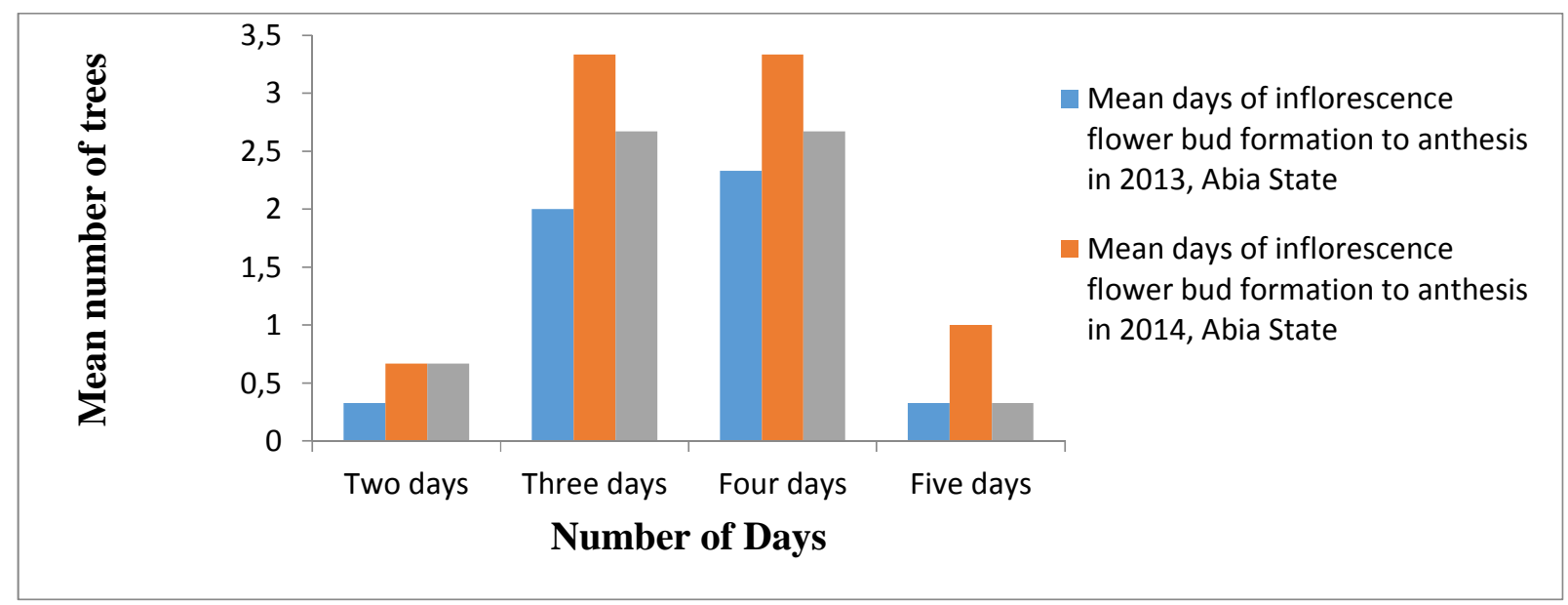

Figure 4: Mean days of inflorescence flower bud formation to anthesis from 2013 - 2015 Abia State

\section{Imo State Flowering Habit (\%)}

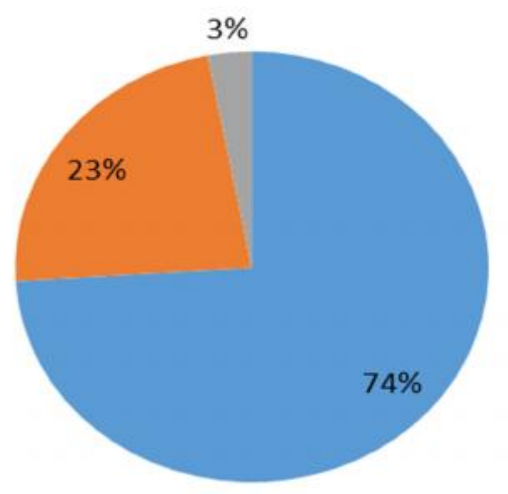

Figure 5: Flowering Habit of $D$. edulis in Imo State locations

\section{Abia State Flowering Habit (\%)}

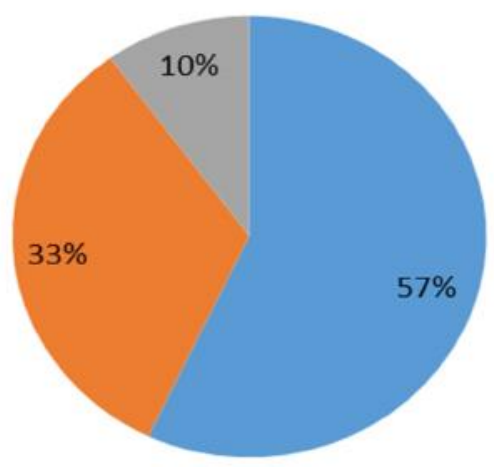

Figure 6: Flowering Habit of D. edulis in Abia State locations

Journal of the Faculty of Agriculture and Veterinary Medicine, Imo State University Owerri website: www ajol.info 
Journal of Agriculture and Food Sciences

Volume 19, Number 2, October 2021, pp 13 - 22

Njoku, T.C.

Table 1: Effect of location on mean inflorescence length (IL) of Dacryodes edulis in Imo State in 2013 - 2015

\begin{tabular}{llllllll}
\hline Year & IMSU & \multicolumn{3}{c}{ Logara } & Umuduru & $\begin{array}{l}\text { Grand } \\
\text { Mean } \\
\end{array}$ \\
& X $(\mathrm{cm})$ & $\mathrm{CV}$ & $\mathrm{X}(\mathrm{cm})$ & $\mathrm{CV}$ & $\mathrm{X}(\mathrm{cm})$ & $\mathrm{CV}$ & $\mathrm{X}(\mathrm{cm})$ \\
& $\mathrm{IL}$ & $(\%)$ & $\mathrm{IL}$ & $(\%)$ & $\mathrm{IL}$ & $(\%)$ & $\mathrm{IL}$ \\
\hline 2013 & $20.33^{\mathrm{a}}$ & 4.46 & $5.64^{\mathrm{b}}$ & 15.49 & $8.77^{\mathrm{b}}$ & 8.12 & 11.58 \\
2014 & $18.74^{\mathrm{a}}$ & 3.95 & $14.79^{\mathrm{a}}$ & 5.53 & $17.53^{\mathrm{a}}$ & 3.70 & 17.02 \\
2015 & $18.60^{\mathrm{a}}$ & 2.71 & $19.34^{\mathrm{a}}$ & 1.92 & $13.81^{\mathrm{a}}$ & 7.41 & 17.25 \\
Total & 57.67 & 11.12 & 39.77 & 12.94 & 40.11 & 19.23 & 45.85 \\
Mean & 19.22 & 3.71 & 1326 & 7.65 & 4.31 & 6.41 & 15.28 \\
\hline
\end{tabular}

Means on the same row followed by the same letters are not significantly

different at ( $\mathrm{p}<0.05)$. $\mathrm{X}=$ Mean value, $\mathrm{CV}=$ Coefficient of variation, $\%=$ Percentage.

Table 3: Effect of location on mean inflorescence per panicle (I/P) of Dacryodes edulis in Imo State in 2013 - 2015

\begin{tabular}{llllllll}
\hline & IMSU & & Logara & \multicolumn{3}{c}{ Umuduru } & Grand Mean \\
& $\mathrm{X}$ & $\mathrm{CV}$ & $\mathrm{X}$ & $\mathrm{CV}$ & $\mathrm{X}$ & $\mathrm{CV}$ & $\mathrm{X}$ \\
Year & $\mathrm{I} / \mathrm{P}$ & $(\%)$ & $\mathrm{I} / \mathrm{P}$ & $(\%)$ & $\mathrm{I} / \mathrm{P}$ & $(\%)$ & $\mathrm{I} / \mathrm{P}$ \\
\hline 2013 & $5.18^{\mathrm{a}}$ & 4.64 & $1.57^{\mathrm{b}}$ & 17.03 & $3.46^{\mathrm{ab}}$ & 8.00 & 3.40 \\
2014 & $4.35^{\mathrm{a}}$ & 4.91 & $4.16^{\mathrm{a}}$ & 6.45 & $5.66^{\mathrm{a}}$ & 2.17 & 4.72 \\
2015 & $5.75^{\mathrm{a}}$ & 3.54 & $6.61^{\mathrm{a}}$ & 3.70 & $6.61^{\mathrm{a}}$ & 3.70 & 6.32 \\
Total & 15.28 & 13.09 & 12.34 & 27.18 & 15.73 & 13.87 & 14.44 \\
Mean & 5.09 & 4.36 & 4.11 & 9.06 & 5.24 & 4.62 & 4.81 \\
\hline
\end{tabular}

Means on the same row followed by the same letters are not significantly different at $(\mathrm{P}<0.05)$. $\mathrm{X}=$ Mean value, $\mathrm{CV}=$ Coefficient of variation, $\%=$ Percentage

Table 5: Effect of location on mean flower per inflorescence (FI) of Dacryodes edulis in Imo State in 2013 - 2015.

\begin{tabular}{llllllll}
\hline Year & IMSU & & Logara & \multicolumn{3}{c}{ Umuduru } & Grand Mean \\
& X & CV & X & CV & X & CV & X \\
& FI & $(\%)$ & FI & $(\%)$ & FI & $(\%)$ & FI \\
\hline 2013 & $15.18^{\mathrm{a}}$ & 4.64 & $16.29^{\mathrm{a}}$ & 15.67 & $11.24^{\mathrm{a}}$ & 9.83 & 14.24 \\
2014 & $92.71^{\mathrm{a}}$ & 12.26 & $82.11^{\mathrm{a}}$ & 13.07 & $21.40^{\mathrm{a}}$ & 8.08 & 65.41 \\
2015 & $110.18^{\mathrm{a}}$ & 11.06 & $100.84^{\mathrm{a}}$ & 10.13 & $45.66^{\mathrm{a}}$ & 17.72 & 118.89 \\
Total & 218.07 & 27.96 & 199.24 & 38.87 & 15.73 & 35.63 & 198.54 \\
Mean & 72.69 & 9.32 & 66.41 & 12.96 & 5.24 & 11.88 & 66.18 \\
\hline
\end{tabular}

Means on the same row followed by the same letters are not significantly different at $(\mathrm{p}<0.05) . \mathrm{X}=$ Mean value, $\mathrm{CV}=$ Coefficient of variation, $\%=$ Percentage

Journal of the Faculty of Agriculture and Veterinary Medicine, Imo State University Owerri website: www ajol.info 
Journal of Agriculture and Food Sciences

Volume 19, Number 2, October 2021, pp 13 - 22

Njoku, T.C.

Table 2:Effect of location on mean inflorescence length (IL)of Dacryodes edulis in Abia State in 2013 - 2015

\begin{tabular}{|c|c|c|c|c|c|c|c|}
\hline \multirow{4}{*}{ Year } & \multicolumn{2}{|l|}{ Oboro } & \multicolumn{2}{|l|}{ Alayi } & \multicolumn{2}{|l|}{ Ngwa } & \multirow{4}{*}{$\begin{array}{l}\text { Grand } \\
\text { Mean } \\
\text { X(cm) } \\
\text { (IL) }\end{array}$} \\
\hline & & & & & & & \\
\hline & $\mathrm{X}(\mathrm{cm})$ & $\mathrm{CV}$ & $\mathrm{X}(\mathrm{cm})$ & $\mathrm{CV}$ & $\mathrm{X}(\mathrm{cm})$ & CV & \\
\hline & (IL) & $(\%)$ & (IL) & $(\%)$ & (IL) & $(\%)$ & \\
\hline 2013 & $19.07^{\mathrm{a}}$ & 4.00 & $13.94^{\mathrm{a}}$ & 10.98 & $14.11^{\mathrm{a}}$ & 9.58 & 15.71 \\
\hline 2014 & $16.96^{\mathrm{a}}$ & 3.81 & $15.83^{\mathrm{a}}$ & 7.27 & $16.13^{a}$ & 4.38 & 16.31 \\
\hline 2015 & $16.83^{\mathrm{a}}$ & 2.23 & $10.55^{\mathrm{a}}$ & 12.03 & $14.69^{\mathrm{a}}$ & 8.10 & 14.02 \\
\hline Total & 52.86 & 10.01 & 40.32 & 30.29 & 44.93 & 22.06 & 46.03 \\
\hline Mean & 17.62 & 3.34 & 13.44 & 10.10 & 14.98 & 7.35 & 15.35 \\
\hline
\end{tabular}

Means on the same row followed by the same letters are not significantly different at ( $\mathrm{p}$ <0.05). $\mathrm{X}=$ Mean value, $\mathrm{CV}=$ Coefficient of variation, $\%=$ Percentage

Table 4: Effect of location on mean inflorescence per panicle (I/P) of Dacryodes edulis in Abia State in 2013 - 2015

\begin{tabular}{|c|c|c|c|c|c|c|c|}
\hline & Oboro & & Alayi & & Ngwa & & $\begin{array}{l}\text { Grand } \\
\text { Mean }\end{array}$ \\
\hline Year & $\begin{array}{l}X \\
(\mathrm{I} / \mathrm{P})\end{array}$ & $\begin{array}{l}\mathrm{CV} \\
(\%)\end{array}$ & $\begin{array}{l}X \\
(\mathrm{I} / \mathrm{P})\end{array}$ & $\begin{array}{l}\mathrm{CV} \\
(\%)\end{array}$ & $\begin{array}{l}\mathrm{X} \\
(\mathrm{I} / \mathrm{P})\end{array}$ & $\begin{array}{l}\mathrm{CV} \\
(\%)\end{array}$ & $\begin{array}{l}\mathrm{X} \\
(\mathrm{I} / \mathrm{P})\end{array}$ \\
\hline 2013 & $11.21^{\mathrm{a}}$ & 13.45 & $0.96^{b}$ & 17.21 & $3.66^{\mathrm{ab}}$ & 1.80 & 5.28 \\
\hline 2014 & $4.25^{\mathrm{ab}}$ & 2.58 & $3.05^{b}$ & 7.03 & $5.11^{\mathrm{a}}$ & 0.85 & 4.14 \\
\hline 2015 & $4.26^{\mathrm{a}}$ & 1.70 & $2.19^{\mathrm{a}}$ & 11.11 & $2.20^{\mathrm{a}}$ & 7.76 & 2.88 \\
\hline Total & 19.72 & 17.73 & 6.20 & 35.35 & 10.97 & 10.41 & 12.30 \\
\hline Mean & 6.57 & 5.91 & 2.07 & 11.78 & 3.66 & 3.47 & 4.10 \\
\hline
\end{tabular}

Means on the same row followed by the same letters are not significantly different at ( $\mathrm{p}<0.05) . \mathrm{X}=$ Mean value, $\mathrm{CV}=$ Coefficient of variation, $\%=$ Percentage

Table 6: Effect of location on mean flower per inflorescence (FI) of Dacryodes edulis in Abia State in 2013 - 2015

\begin{tabular}{llllllll}
\hline Year & $\begin{array}{l}\text { Oboro } \\
\text { X } \\
(\mathrm{FI})\end{array}$ & $\mathrm{CV}(\%)$ & $\begin{array}{l}\text { Alayi } \\
\mathrm{X} \\
(\mathrm{FI})\end{array}$ & $\mathrm{CV}(\%)$ & $\begin{array}{l}\text { Ngwa } \\
(\mathrm{FI})\end{array}$ & CV $(\%)$ & $\begin{array}{l}\text { Grand Mean } \\
(\mathrm{FI})\end{array}$ \\
\hline 2013 & $27.51^{\mathrm{a}}$ & 4.64 & $23.33^{\mathrm{a}}$ & 9.35 & $15.69^{\mathrm{a}}$ & 10.13 & 22.18 \\
2014 & $27.89^{\mathrm{a}}$ & 3.86 & $19.75^{\mathrm{a}}$ & 7.38 & $28.68^{\mathrm{a}}$ & 4.19 & 25.44 \\
2015 & $25.99^{\mathrm{a}}$ & 2.95 & $10.74^{\mathrm{b}}$ & 10.97 & $16.4^{\mathrm{ab}}$ & 9.17 & 17.71 \\
Total & 81.39 & 11.45 & 53.82 & 27.70 & 60.77 & 23.49 & 65.33 \\
Mean & 27.13 & 3.82 & 17.94 & 9.23 & 20.26 & 7.83 & 21.78 \\
\hline
\end{tabular}

Means on the same row followed by the same letters are not significantly different at $(\mathrm{p}<0.05)$. $\mathrm{X}=$ Mean value, $\mathrm{CV}=$ Coefficient of variation, $\%=$ Percentage 


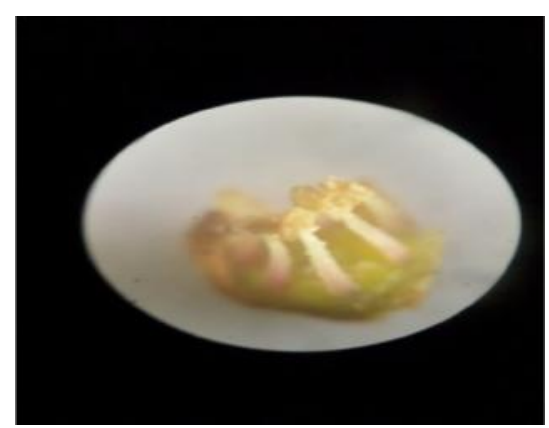

Plate 1: Male flower view through a microscope

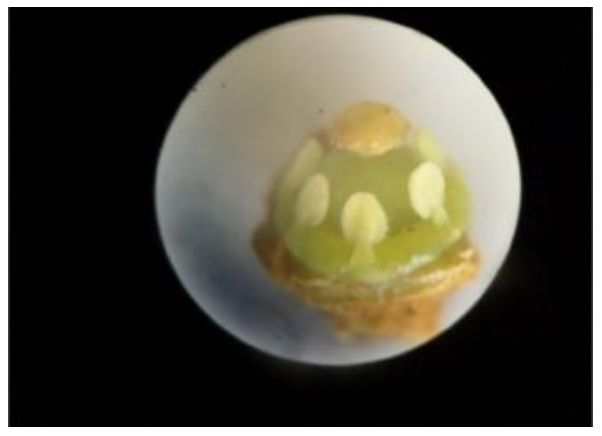

Plate 2: Hermaphrodite Flower view through a microscope

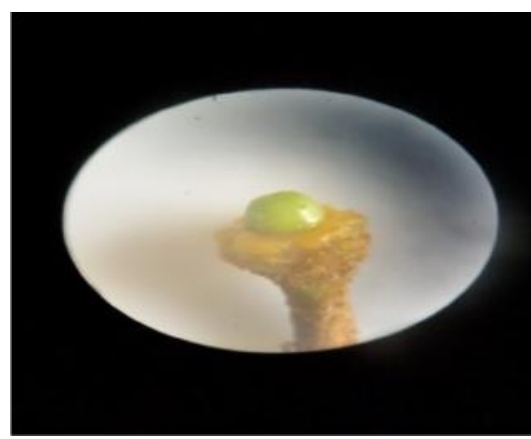

Plate 3 : Female Flower viewed through a microscope.

Journal of the Faculty of Agriculture and Veterinary Medicine, Imo State University Owerri website: www ajol.info 